\title{
Analyzing the Causes and Effects of Rural Landscape Changes: The Case of the Ordu Province of Eastern Black Sea Basin (Turkey)
}

\author{
Kırsal Peyzajların Değişimlerinin Nedenleri ve Etkilerinin Analizi: \\ Doğu Karadeniz-Ordu ilii Örneği
}

Berna DIKÇINAR SEL

Building on the perspective that indigenousness of cultural landscapes must be protected, the present article studies the changes on landcover/landuse; one of the most important components of cultural landscapes. The aim is to provide data for future planning studies protecting cultural landscapes. This study is carried out in three stages. In the first stage, landcover is investigated in five time points (1990, 2000, 2006, 2012, and 2018), in four main categories (artificial surfaces, agricultural areas, forest areas, water bodies), and the changes are reported comparatively. In the second stage, examinations are detailed according to the first stage's results. Transitions among categories which led to significant changes, and the transition process is analyzed. Landscape Transition Matrix and transition intensities are calculated for three time points and two time periods. In the last stage, landcover transitions according to subclasses are analyzed. In the conclusions section, causes and effects of the changes are discussed. This study is providing detailed inputs to future solutions by incorporating the landcover categories among which the transitions occurred, periods of these transitions, and analyzing the intensity of the subclasses. The sample area selected is Ordu province in the Eastern Black Sea Region, where the climate with high precipitation, harsh topography, its forests, scattered settlement pattern, agricultural production, and migration activities differentiate among the Anatolian Peninsula. The results of the analyses are indicating that the landcover changes are against the agricultural and forest areas, and the problem lies within the uncontrolled expansion of hazelnut gardens.

Keywords: Cultural landscape; landscape changes; rural landscape.

Bu makalede kültürel peyzajların yere özgü olma durumlarının korunması gerekliliği yaklaşımından hareketle, kültürel peyzajların en önemli bileşenlerinden biri olan arazi örtüsü/kullanımındaki değişimlerin analiz edilmesine yönelik yapılan çalışma aktarılmaktadır. Çalışmada, kültürel peyzajların korunması için yapılacak planlama çalışmalarına veri aktarılması amaçlanmıştır. Çalışma üç aşamada gerçekleştirilmiştir. Birinci aşamada arazi örtüsü, beş zaman kesitinde (1990, 2000, 2006, 2012, 2018), dört temel kategoride (yapay yüzeyler, tarımsal alanlar, orman alanları, su yüzeyleri) incelenmiş ve karşılaştırmalı olarak değişiklikler saptanmıştır. İinci aşama birincinin sonuçlarına göre analizin derinleştirildiği aşamadır. Öne çıkan değişimlerin, hangi kategoriler arasındaki geçişlerle olduğu ve bu geçiş süreci analiz edilmektedir. Üç zaman kesiti ve iki zaman aralığı için, peyzaj geçiş matrisi oluşturulmuş ve geçiş yoğunlukları hesaplanmıştır. Son aşamada, arazi örtüsü geçişlerinin alt kategorilere göre geçiş durumları analiz edilmektedir. Makale kapsamında analiz sonuçları bağlamında, meydana gelen değişimlerin nedenleri ve etkileri de tartışılmaktadır. Çalışma, değişimlerin hangi arazi örtüsü kategorileri arasındaki geçişleri içerdiği, bu geçişlerin dönemleri ve alt kategoriler bazında yoğunluğunu da analiz ederek, üretilecek çözümlere detaylı girdiler sağlayabilmesi açısından farklılaşmaktadır. Analizlerin uygulandığı örnek alan Anadolu Yarımadasında yağışlı iklimi, sert topoğrafyası, ormanları, seyrek yerleşme deseni, tarımsal üretimi ve göç hareketleri ile farklılaşan Doğu Karadeniz Bölgesi ve bölgede öne çıkan yerleşmelerden Ordu ili olarak seçilmiştir. Analizler sonucunda Doğu Karadeniz Bölgesi Ordu ili arazi örtüsünde meydana gelen değişimlerin genelde tarımsal alanlar ve orman alanları aleyhine gelişen yapısı, detayda ise tarımsal alanların alt sınıflaması olan meyve ağaçları sınıflaması içerisinde yer alan fındık bahçelerinin kontrolsüz genişlemesi sorunları olduğu ortaya konulmaktadır. Anahtar sözcükler: Kültürel peyzaj; peyzaj değişimleri; kırsal peyzaj.

Department of Urban and Regional Planning, Yıldız Technical University Faculty of Architecture, İstanbul, Turkey

Article arrival date: January 01, 2021 - Accepted for publication: March 17, 2021

Correspondence: Berna DIKÇINAR SEL. e-mail: bernasel@gmail.com

○ 2021 Yıldız Teknik Üniversitesi Mimarlık Fakültesi - ๑ 2021 Yıldız Technical University, Faculty of Architecture 


\section{Introduction}

It is undeniably important that an increasing volume of the world population is living in cities, and in that context the cities are expanding especially towards rural areas. Increasing population, rapidly exhausting and consumed sources, hunger, poverty and global climate change are being faced as the biggest problems that are threatening our world on a global scale ${ }^{1}$. While the studies about sustainability of rural areas are increasing, it's becoming very important to protect the nature/natural structure and human relationship in its authentic forms. This relationship is described by the terms "soil, land, landcover/landuse, urban, rural, landscape and cultural landscape" in these studies. Cultivation and grading processes leads to different cultural landscapes in different geographies and climates. The cultural landscape which is indicated with the terms endemism, rareness and integrity represents an equally important aspect of identity as much as a biological entity. With their vital importance; cultural landscapes are listed in the World Heritage List and are also defined as the characteristic product of the mutual interaction of human communities in a specific location with their cultural attribution and potentials (Rössler 2002; Rössler 2005; Brown et. al. 2005). In addition, "this heritage is also an engine of development. Its preservation is fundamental and gives meaning to the development of our societies. It is our responsibility to recognise the value of the past, and to protect and promote this heritage, an essential factor in economic, social and cultural development. Adopted in Hanover in September 2000 by the Ministers responsible for the regional planning of the Council of Europe's Member States and endorsed in the Recommendation (2002) 1 of the Committee of Ministers, the Guiding Principles for Sustainable Spatial Development of the European Continent detail a series of measures to foster development of rural areas as life settings for both economic and recreational activity and as natural environments. "European Rural Heritage Observation Guide - CEMAT" contributes to the implementation of the Recommendation of the Committee of Ministers: helping to restore the town-countryside balance and seeking to promote the rural world's resources as a development factor. It is indeed essential to put these principles into effect so as to promote sustainable rural planning combining economic growth and protection of the heritage assets inherent in both natural and cultural landscapes" (CEMAT 2003).

Both the protected areas that made it in the World Heritage List and the rest of the cultural landscape areas are going through changes and transformations caused

\footnotetext{
UNDP: https://www.undp.org/content/undp/en/home/sustainable-development-goals.html [Accessed 4 Sept. 2020], UNFPA (2019), State of World Population 2019, UNFPA Division of Communications and Strategic Partnerships.
}

by the threats of urbanization (Su et.al. 2011), migration, economic crises etc. A 2017 Report from European Environment Agency that is analyzing landscape transitions through the changes in landuse/landcover starts with the statement "Landscape is one of the most important assets that contributes to Europe's cultural identity"2 (Stobbelaar \& Pedroli 2011). Referring to Sustainable Development Goals "Terrestrial Ecosystems (G.15)" and "Sustainable Cities and Communities (G.11)"; the same report emphasizes the protection of landscapes by stating that a Landscape vision is needed where the balanced development of urban and rural areas, and life quality is provided ${ }^{3}$.

Studies regarding the sustainability of rural areas aims firstly to define the existing landscapes and the changes in them. These definitions are generally made by detecting and evaluating the landcover/landuse changes (Gulinck\&Wagendorp 2002; Kizos \& Primdahl 2010; Wijetunga \& Sang Sung 2015; Rovai et. al 2016; Tieskens et. al 2017) throughout the historical process.

The present study departs from the assumption that one of the most important components of providing the sustainability of cultural/rural landscapes is the landcover. In this study, causes and effects of landcover changes are discussed, and answers to the following research questions are being searched through analyses and examinations: (1) Characteristics of the landscape change in the study area in general; (2) Differences in this landscape change according to landuse categories and time intervals when the research was made; (3) Probable causes of the change; (4) Existing and potential issues caused by the change.

\section{Materials, Methods and Analysis}

\section{Data Structure}

The study area had been determined as Ordu province in the analysis scale, and Eastern Black Sea Region in the upper scale with its quite varying agricultural products and socio-economical characteristics due to its climate and geographical characteristics. There are three important reasons for the selection of Eastern Black Sea Region as the study area. Firstly, it is amongst the regions that have lowest urbanization rates; Secondly, migration outside the region especially occurs from its rural parts; Thirdly, even though the migration rate from rural areas is high, the Hazelnut fruit production -which Turkey is supplying $70 \%$ of the products worldwide ${ }^{4}$ - is being made

\footnotetext{
EEA Report, (2017) Landscapes in transition an account of 25 years of land cover change in Europe, EEA Report, 2017, No 10/2017, ISSN 1977-8449, European Environment Agency.

3 UNDP: https://www.undp.org/content/undp/en/home/sustainable-development-goals.html [Accessed 4 Sept. 2020]

42018 Yılı Fındık Raporu (Hazelnut Report), (2019) T.C.Ticaret Bakanlığı (Republic of Turkey-Ministry of Trade), Esnaf, Sanatkarlar Ve Kooperatifçilik Genel Müdürlüğü, Nisan 2019, Ankara. http://www.tmo.gov.tr/Upload/ Document/findiksektorraporu2018.pdf [Accessed 4 Sept. 2020]
} 
predominantly in this region. In other words, although the region is experiencing migration from its rural areas, it has the largest hazelnut gardens that are supplying $60 \%$ of hazelnut production in the country. This aspect had been the determinator of the landcover, and consequently the rural landscape (Eryılmaz\&Kılıç 2019). Another important issue in this region is the increase in mining areas. In this context, the focus of this study is to analyze and evaluate the changes in this dominant landcover in its course.

Landscape change analyses about changes in landcover and landuse throughout the time, generally focus on the amounts of "difference" and "change", and the categories which land change has occurred between. However, the intensity of land use change, its impact on the cultural landscape and the ability to make predictions for the future are also very important (Li et al. 2010; Zhang et al.2017). Aldwaik \& Pontius Jr. (2012) are proposing another method to analyze landcover and landuse; which uses three (or more) time points and two (or more) time intervals; which they named "Intensity Analysis and Landscape Transition Analysis". In this method, instead of the net increase in the quantity of category transitions, change rates and the speed of change within the studied time interval and the states of the dormant categories and category areas are calculated, and the results are interpreted accordingly.

As in the Aldwaik \& Pontius Jr.'s study, in the analysis of this study, the densities of transition according to time intervals have been calculated. CORINE ${ }^{5}$ data were used in all analyzes. CORINE data consist of 44 classes, and had been produced in 1990, 2000, 2006, 2012, and 2018. In this study, all five time points had been included in the research in the context of overall valuation where the main landcover categories are investigated. The examination of transition intensities and the transitions between land categories had been made with the data through the time points 2006, 2012, and 2018.

\section{Analysis}

\section{Categorical Evaluation of Landcover between $1990-2018$}

In the first stage of the study, CORINE landcover maps are investigated in four main categories (artificial surfaces, agricultural areas, forest and semi-natural areas, and water bodies) and five time points (1990, 2000, 2006, 2012, and 2018). The aim is to demonstrate dimensional ratios and changes of the categories in five different time points, and to present the circumstances about the transitions between categories in general. Thematic maps and pie charts for the analysis, showing the five time periods and four main categories had been generated in GIS.

\footnotetext{
5 EEA, Copernicus Monitoring Earth from Space and The Ground, European Enviroment Agency, 2019 Published on 30 Sep 2019.
}

Landcover ratios in 1990 consists of 0.44 agricultural areas, 0.55 forest areas, and 0.01 artificial surfaces and inland waters (Fig. 1a). These ratios are numerically displaying the rural character and structure of the area. Eastern Black Sea Region's unique structure, as stated in the section where the region characteristics was defined, is forest areas in high altitudes reflecting the high precipitation rates, agricultural areas in low altitudes, and settlement areas where the valleys reach the sea; is being expressed in ratios.

Landcover ratios in 2000 consists of 0.43 agricultural areas, 0.56 forest areas, and 0.01 other areas. In both of the time points agricultural areas and forests are defining 0.99 of the area, and the largest landcover category is forest areas (Fig. 1b). In the 10 years between the first and the second analysis points, there had been no significant changes regarding the landcover.

Regarding the landcover ratios in 2006, agricultural and forest uses from the main four categories covers 0.98 of the area. The remaining 0.02 consists of artificial surfaces (0.01) and inland waters (0.01). Difference from 1990 and 2000 points is the approx. 7\% decrease in forest areas (decreasing from 0.55 to 0.48 ) and the $6 \%$ increase in agricultural areas (from 0.44 to $50 \%$ ). Ratios of other areas also increased; from 0.01 to 0.02 . These ratios are demonstrating the transition from forest areas to agricultural and artificial areas in a matter of 6 years between 2000 and 2006 (Fig. 1c).

Differences in the ratios caused the necessity to evaluate the subcategories as well. Within the Artificial Surfaces category, almost twice as much dimensional enlargement had been identified in the following subcategories: continuous urban fabric, industrial and commercial units, mineral extraction sites, and construction sites.

- In 2006 time point, agricultural areas are covering 0.50 of the settlement. Analyzing the types of the agricultural areas; we see that 0.65 of agricultural areas are formed by heterogeneous agricultural areas. The subclasses of heterogeneous agricultural areas are complex cultivation patterns and land principally occupied by agriculture ${ }^{6} .0 .34$ of agricultural areas are in the Fruit Trees and Berry plantation ${ }^{7}$ class, which is defined under the Permanent Crops classification (Fig. 1c).

- Detailing the forest areas according to their subclasses; an area that covers the 0.58 lies under

\footnotetext{
6 Complex Cultivation patterns; Mosaic of small cultivated land parcels with different cultivation types -annual crops, pasture and/or permanent crops-, eventually with scattered houses or gardens. Land principally occupied by agriculture; Areas principally occupied by agriculture, interspersed with significant natural or semi-natural areas (including forests, shrubs, wetlands, water bodies, mineral outcrops) in a mosaic pattern. (https://land. copernicus.eu/user-corner/technical-library/corine-land-cover-nomenclature-guidelines/html/index-clc-242.html)
} 


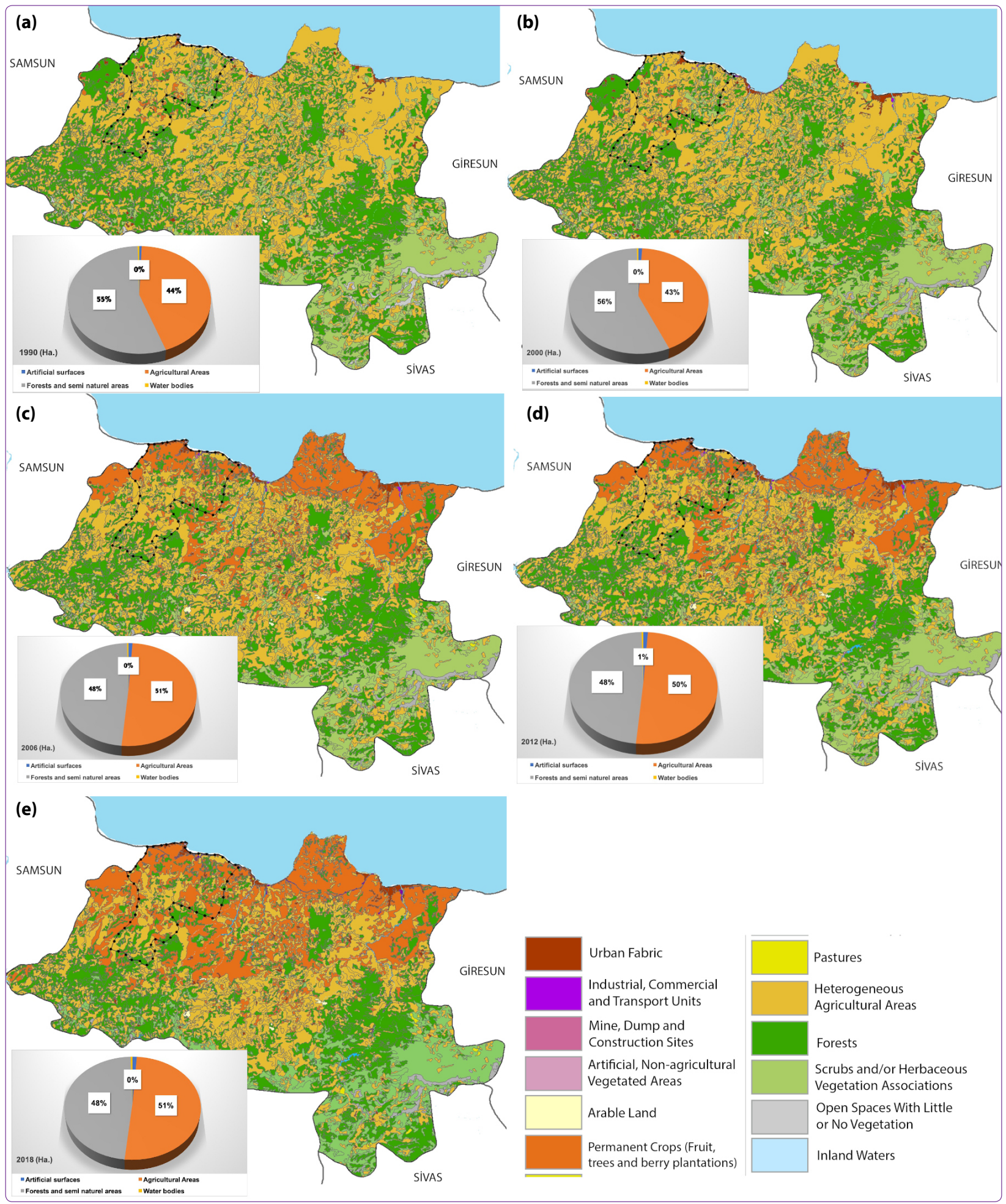

Figure 1. Ordu Landcover, 1990-2018.

the Forest subclass. In this subclass, there are broad leaves Forest, mixed Forest, and coniferous Forest areas, listed according to their sizes respectively. The second big group is the Scrub and/or herbaceous vegetation association group that covers the 0.36 of forest areas (Fig. 1c).
Landcover ratios in 2012 are not showing any major changes in the categories. As in 2006, agricultural areas and forest areas cover 0.98 of the area, and the ratios of subcategories are the same. Data also reveals that the ratio covered by Artificial Surfaces category area has also remained unchanged. However, the subclass Industrial, 
Commercial and Transport Units of the Artificial Surfaces category had doubled both by dimension and ratio (Fig. 1d).

Ratios of landcover categories in 2018 have remained more or less the same, except the minor changes. Agricultural areas remained at 0.50 , and the forest areas decreased by the ratio of approx. 0.01 and became 0.47 . According to 2018 data, there is a change in the distribution of the subtypes of agricultural areas: the ratio of fruit trees and berry plantation under the title Permanent Crops has raised to 0.42 from 0.34 . Heterogeneous agricultural areas have decreased to 0.57 from 0.65 (Fig. 1e).

The results of landcover analysis by years could be summarized as follows:

- Forest and agricultural areas that define the main characteristic of the region has decreased by the ratio of $2 \%$ between the first year of analysis, 1990, and the last year 2018.

- Change only in the forest areas had been an $8 \%$ decrease from 1990 to 2018.

- Agricultural areas have increased by the ratio $7 \%$.

- Artificial surfaces have increased by the ratio $0.6 \%$.

- At the end of this stage, analysis results show net transitions from forest category to other categories.

The next stage, "Landscape Transitions Analysis" aims to analyze the transitions within time periods considering also the subcategories, and to determine transition intensities in order to make detailed examination and identifications of first stage results on landcover changes.

\section{Landscape Transitions Analysis Based on Main Land Categories}

In this stage of the study, transitions ${ }^{8}$ between landcover categories had been analyzed for two time periods and three time points with the landcover values for the years 2006, 2012, and 2018. A transition matrix had been developed by a method that considers primarily the prominent categories ${ }^{9}$ from the results of landcover analysis in the study area for the duration of five years (Aldwaik 2012; Zhang et al. 2014). Categories which are formed by the development of the matrix is then analyzed for the status of being active or dormant, and the study is concluded with a comprehensive examination of both of these statuses. In these comprehensive analyses first the ratios of gains and losses of the categories that experienced

\footnotetext{
8 Transitions between categories are calculated by data provided by CORINE where the transition data in difference maps and charts is given in hectares.

9 When determining the categories for matrix, classification had been made depending on the main categories that define the landcover, and the results of the overall evaluation analysis. Correspondingly, the subclassification Mineral Extraction had been included in the matrix as a separate category from Artificial Surfaces, because according to the results of the first analysis, this category has expanded vastly between 1990-2018.
}

land transformation had been calculated according to their categories. In this way, determining the intensity and speed was intended. Secondly, the transition distributions of the main categories in terms of the subcategories, and the overlay maps of the prominent ones from these distributions were generated.

The transition matrix is defining the land transitions in the periods between 2006-2012 and 2012-2018. In the matrix, the rows are showing the values of the categories from an initial time, and the columns are showing the values of the categories from a subsequent time (light colored rows show the data for the period of 2006-2012, and the dark colored rows show the data for the period of 2012-2018). Data on the diagonal shows the dormant area values (underlined data) that haven't transitioned. In this manner, the transition patterns and intensities between categories happened in the region had been attempted to be defined.

When the matrix data is examined, total land area of the category transition happened in two time periods in the matrix had been determined as 3,027 ha. Agricultural areas had been revealed as the category that lost most land with total of 1,702 ha. Total loss of forest areas had been calculated as $975 \mathrm{ha}$.

Considering the two-time intervals, the category that has gained the most land cumulatively is Urban Fabric + Industrial, Commercial and Transport Units + Construction Sites with 1,705 ha. The second in this classification is the Mineral Extraction category with 412 ha gained area.

The intensity of gain and/or loss is determined by proportioning the land gain and/or loss of the categories, and the land remained dormant within the time periods of two separately analyzed time intervals. Figure 2 defines the amounts among which categories and which rates of land transitions happened in the agricultural and forest category, which has the highest loss. Accordingly, the loss of agricultural areas is $0.16 \%$ in $2000-2012$ time period, and $0.28 \%$ in $2012-2018$ time period. This means that agricultural areas have lost 16 hectares of every 1000 hectares of agricultural land in the first period, and 28 hectares of every 1000 hectares in the second. This observation shows us the agricultural land loses had been accelerated in 2012-2018 period (Fig. 2).

Analyzing the transitions from forest areas to other categories shows us the loss in the first time period is $0.09 \%$, and $0.18 \%$ in the second period. These values are showing that the land loses in 2012-2018 time period is also accelerating, similar to agricultural areas. Furthermore; while $62 \%$ of transitions from forest areas are to urban fabric + industrial, commercial and transport units + construction sites category in the first time period, in the second period $47 \%$ of transitions are to agricultural areas. 
These rates are confirming the evaluations of the first level of the study, which was the existence of transitions from forest areas to agricultural areas, but showing they are not as excessive and sharp as the results of the first analysis suggested. And even though there are transitions from forest areas to agricultural areas, land loss in agricultural areas are greater in terms of both the cumulative value and intensity values.

Figure 2 clearly shows the majority of transitions is from forest and agricultural areas to Urban Fabric category; both in the first time period and the second. Furthermore, Urban Fabric category has increased its land size by $8.37 \%$ in $2006-2012$ period and $14.17 \%$ in $2012-2018$ period. Lands that Urban Fabric category gained from agricultural areas had been calculated as $65 \%$ in $2006-2012$ period and $88 \%$ in 2012-2018 period (Fig. 2).

Lands gained by Mineral Extraction category are 36.5\% in $2006-2012$ period and $110 \%$ in $2012-2018$ period. Mineral Extraction category is the category that most land gain occurred. The gains in this category are from the Forest Areas; with rates 47\% in 2006-2012 period and 62\% in 2012-2018 period (Fig. 2).

Results of transition matrix analyses indicates that artificial surfaces had gained the most land, and these gains are from the forest and agricultural areas; even though agricultural areas experienced the most loss, transitions from forest areas to agricultural areas had also been intense especially in 2012-2018 period; forest areas

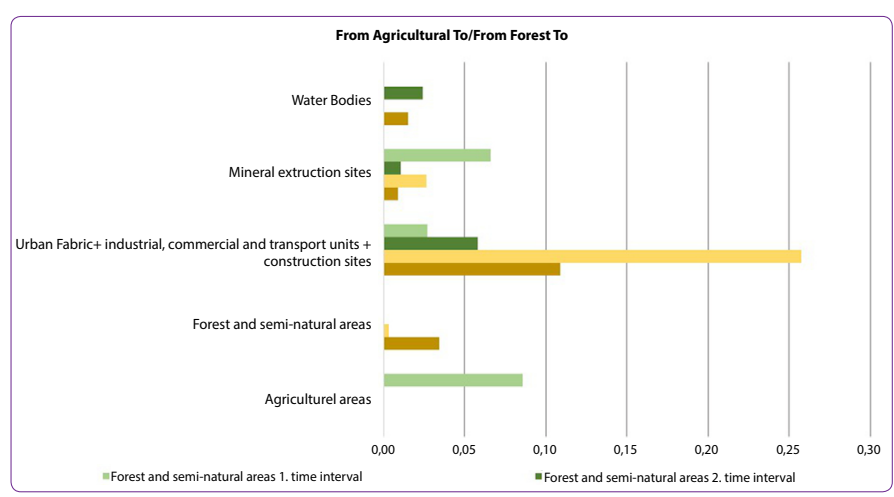

Figure 2. Density of transition from agriculture and forest to others.

had transitioned into all categories, but most intensely to mineral extraction category (Fig. 2).

Comparing the results achieved from this stage of the study with the results of the first stage, we can conclude that landcover categories have not changed significantly between the years 2006 and 2012; the ratios have remained more or less the same. But the analysis based on the transitions in the second stage shows that the landscape change rate has accelerated in 2012-2018 period. The loss rates in Agricultural and Forest areas had been calculated higher than 2006-2012 period.

Transitions based on Landcover Subcategories

Along with the transitions from one landcover category to another, there are also transitions between the subclasses of the categories. In analyzing these transitions, overlay

Table 1. Landscape Transition Matrix

\begin{tabular}{|c|c|c|c|c|}
\hline \multicolumn{5}{|c|}{ Final Year Time Interval } \\
\hline $\begin{array}{c}\text { Agricult. } \\
\text { areas }\end{array}$ & $\begin{array}{l}\text { Forest\& } \\
\text { semi- } \\
\text { naturel } \\
\text { areas }\end{array}$ & $\begin{array}{c}\text { Urban Fabric+ } \\
\text { industrial Commercial } \\
\text { and transp. } \\
\text { units+construct.sites }\end{array}$ & $\begin{array}{l}\text { Mineral } \\
\text { extruction } \\
\text { sites }\end{array}$ & $\begin{array}{l}\text { Water } \\
\text { bodies }\end{array}$ \\
\hline
\end{tabular}

Initial Year of Time Interval

Agricult. Areas

Forest\& semi-naturel areas

Urban Fabric+industrial Commer. and transp.units+construct.sites Mineral Extruction sites

Water Bodies

Final Total

Gross Gain

$\begin{array}{ccc}\underline{368.430} & 13 & 949 \\ \frac{\mathbf{3 8 2 . 2 4 4}}{300} & \mathbf{1 3 2} & \mathbf{3 1 6} \\ \mathbf{0} & \underline{\mathbf{3 6 4 . 4 2 7}} & 94 \\ 0 & 171 & \mathbf{2 1 1} \\ \mathbf{0} & \mathbf{0} & \underline{7.567} \\ 0 & 0 & \mathbf{7 . 5 5 5} \\ \mathbf{8} & \mathbf{0} & 0 \\ 0 & 0 & \mathbf{0} \\ \mathbf{0} & \mathbf{0} & 28 \\ 368.730 & 349.791 & \mathbf{5} \\ \mathbf{3 8 2 . 2 5 2} & \mathbf{3 6 4 . 5 6 0} & 8.639 \\ 300 & 184 & \mathbf{8 . 1 8 8} \\ \mathbf{8} & \mathbf{1 3 3} & 1.072 \\ & & \mathbf{6 3 3}\end{array}$

$\begin{array}{cc}\text { Initial } & \text { Gross } \\ \text { total } & \text { loss }\end{array}$

\begin{tabular}{cccc}
98 & 0 & 369.490 & 1.060 \\
$\mathbf{3 3}$ & $\mathbf{5 8}$ & $\mathbf{3 8 2 . 8 8 6}$ & $\mathbf{6 4 2}$ \\
241 & 0 & 350.243 & 636 \\
$\mathbf{3 8}$ & $\mathbf{8 8}$ & $\mathbf{3 6 4 . 7 6 6}$ & $\mathbf{3 3 9}$ \\
0 & 0 & 7.738 & 171 \\
$\mathbf{0}$ & $\mathbf{1 3 8}$ & $\mathbf{7 . 6 9 3}$ & $\mathbf{1 3 8}$ \\
$\underline{308}$ & 0 & 308 & 0 \\
$\underline{\mathbf{2 0 0}}$ & $\mathbf{0}$ & $\mathbf{2 0 8}$ & $\mathbf{8}$ \\
\hline 0 & $\underline{3.509}$ & 3.537 & 28 \\
$\mathbf{0}$ & $\underline{\mathbf{2 . 9 2 9}}$ & $\mathbf{2 . 9 3 4}$ & $\mathbf{5}$ \\
647 & 3.509 & $\underline{\mathbf{7 3 1 . 3 1 6}}$ & 1.895 \\
$\mathbf{2 7 3}$ & $\mathbf{3 . 2 0 9}$ & $\underline{\mathbf{7 5 8 . 4 8 7}}$ & $\mathbf{1 . 1 3 2}$ \\
339 & 0 & 1.895 & \\
$\mathbf{7 3}$ & $\mathbf{2 8 6}$ & $\mathbf{1 . 1 3 2}$ &
\end{tabular}




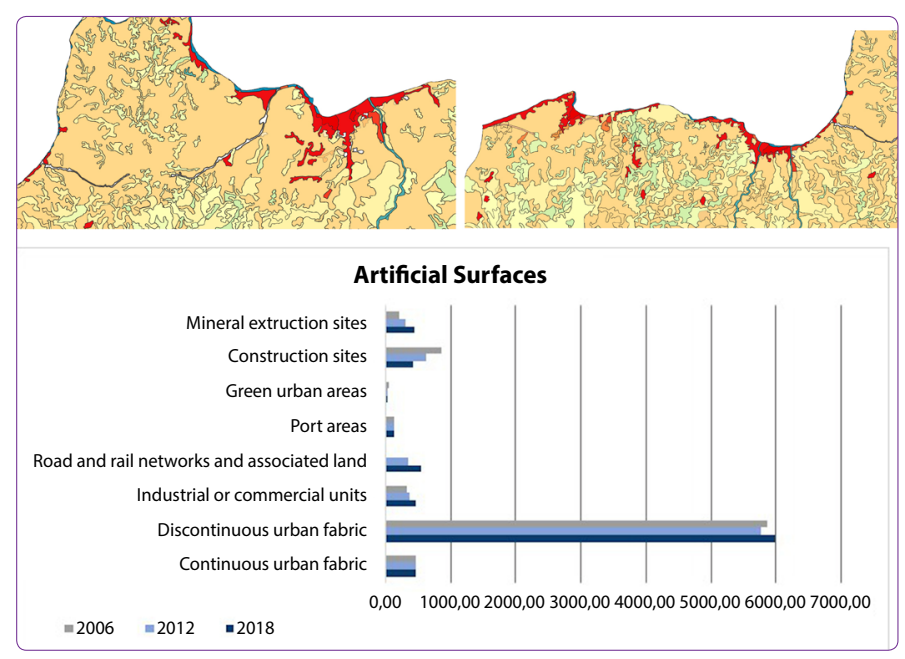

Figure 3. Transition from other categories to Artificial Surfaces (2018).

analysis and the graphics of the values for subclasses in three time points had been used.

2006-2012-2018 time points for subclasses of artificial surfaces show almost all subclasses have increased in size, with the exception of the remarkable decrease in green urban areas category. Transition in green urban areas class is to construction sites, which is another subclass of artificial surfaces.

Discontinuous Urban Fabric subclass shows the biggest expansion in artificial surfaces category. Overlapping the urban areas in the landcover maps of 1990 and 2018 clearly shows the expansion and spread processes of transitions from agricultural areas to urban areas. As it can be understood from the figure, urban areas are spreading by surpassing the topographic and landscape thresholds (Fig. 3).

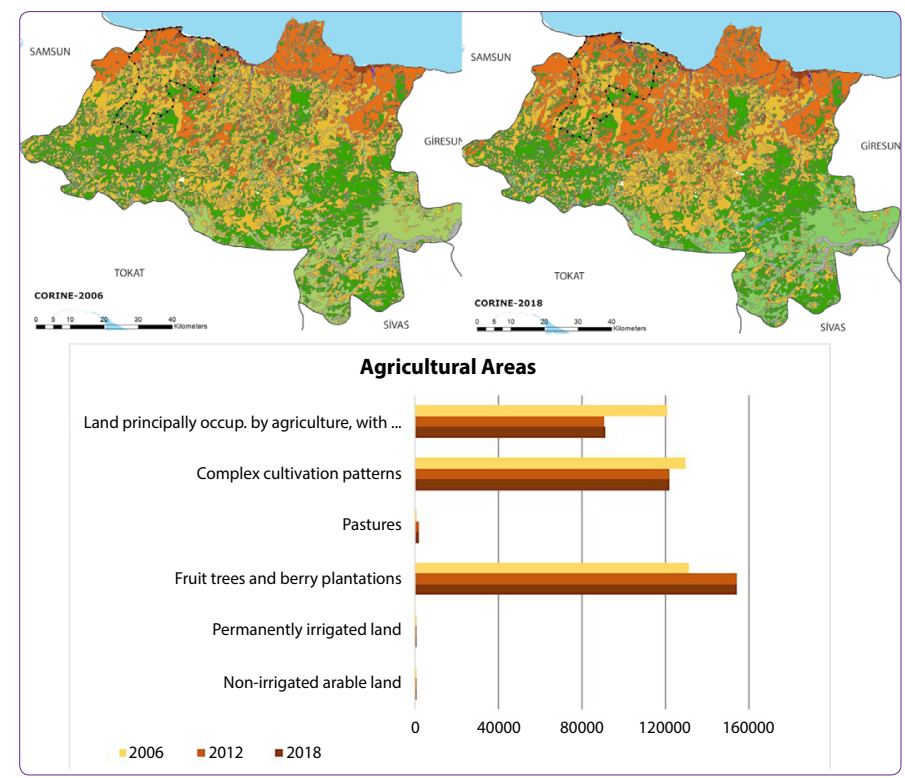

Figure 4. Transition Between Subclassess in Agricultural Areas.
Analyzing the subclasses of agricultural areas; we see that land size ranking in the initial time point 2006 was Fruit trees and berry plantations, Complex cultivation patterns, and Land principally occupied by agriculture, with significant areas of natural vegetation. This ranking remains the same in time points 2012 and 2018. However, evaluating the land sizes and landscape transitions, we see that the subclass fruit trees, and berry plantations have expanded its area by $18 \%$. Considering the absence of sufficient data about these transitions in CORINE difference charts, it's been attempted to determine the subclass that the transitions are usually from with the overlay analysis of the maps of the time points 2012-2006 (Fig. 4).

Through overlay analysis, it's been identified that these transitions are from the classes complex cultivation and Land principally occupied. As Figure 4 suggests, Fruit trees class have expanded in size with the transitions from other agricultural categories. Fruit trees class is a classification that also includes the hazelnut gardens. It won't be a wrong evaluation to assess that this class in the study area Ordu is comprised fully of hazelnut gardens. These data are indicating that the increase in hazelnut gardens and hazelnut cultivation areas will impact the pattern of other agricultural products, and therefore will become an important threat to rural landscape change and transition.

As a result of the analyses, three important landscape transitions that are causing the rural and cultural landscape of Ordu to become delicate and vulnerable had been detected. The first one is the expansion and spreading of the artificial areas, more specifically urban areas, to rural areas, which is also one of the most important problems globally. The second one is the expansion process of hazelnut gardens that is threatening other landcover and landuses, which we can also consider as the decrease in the product range in agricultural areas. Lastly, the increase in mineral extraction areas is threatening the landscape in the region.

\section{Conclusions and Discussion}

Loss of agricultural areas -or in a broad term 'arable areas'- because of the expansion and spreading of the cities, and their transition into built-up areas, is a global problem. Cities are expanding and spreading by absorbing the agricultural areas that are surrounding them (Jepsen et al. 2010; Beilin et al. 2013). This type of transition is defined as the most encountered transition type in the report prepared by the European Environment Agency about landscape transitions based on CORINE data ${ }^{10}$.

Analyses carried out for the province of Ordu within the Eastern Black Sea Region have shown that majority of

${ }^{10}$ EEA, Manual of CORINE Land Cover Changes, EEA Subvention, 2011, Prepared by: Gy. Büttner and B.Kosztra, 30 Nov 2011, Project Manager: Gy. Büttner. 
the transitions are to artificial surfaces; both cumulatively and proportionally (Urban fabric within this category has grown by $15 \%$ of its area). This illustrates a spreading process towards agricultural areas, especially from urban areas. Geographical characteristics of the region is the determinant of the spreading pattern of urban area, and the spreading occurs by pushing the circumstances of topography and thresholds to their limits (Fig. 3).

City centers in the coastal zone are expanding their built-up areas towards agricultural areas by transitioning the valleys and hillsides into compact surfaces in the direction of coast and road axes, and towards the southern direction. A similar situation happens in the settlements located in the mountain zone, but only for the areas that transport network is allowing to have high accessibility levels. As a consequence of the decreasing population due to migration from mountain zone settlements, urban sprawl happens either slightly or none at all. Urban sprawl causes alterations in settlement layout and pattern that is not in line with the rural character of the region, and it is affecting the agricultural production and rural life which establishes the foundation of region's cultural structure (Salvati \& Carlucci 2015, Junaid et al. 2020).

On the other hand, the unplanned increase in settlements and artificial surfaces are causing floods in the region which are getting progressively more frequent in the recent years. Flooding events caused by excessive precipitation lead to tons of hazelnuts to wash out to sea in 2018, and the hazelnut harvest to be damaged in 2019 when there were also landslides caused by the excessive rain $^{11}$ (Gürgen 2004).

With a law issued in 2014, some cities -including Ordu- in their entireties (including the rural areas) had been moved to urban area status administratively. Therefore, the agricultural areas and villages located in rural areas have passed to community neighborhood status (Çopuroğlu 2017). This has caused the settlements with rural characters to be recognized as urban areas (Beynon et al. 2016) and therefore induced a highly conflicting position. Because with the aforementioned law, administration and service format for urban areas are being implemented for rural areas. Unifying the urban and rural areas under the same structure, while both areas require different services in constitutional and operational circumstances, poses a threat for the capability of providing the required services in rural areas and the potential change in rural structure that is already losing population due to migration.

Another trigger that causes the increase in urban growth and artificial areas are transportation investments. Black Sea Coastal Highway has opened in 2007, after 20

${ }^{11}$ https://www.hurriyet.com.tr/yerel-haberler/ordu/orduda-saganak-findigi-vurdu-41310816 [Accessed 4 Sept. 2020] years of construction process. The project design of this investment was made in the 1960's, and this coastal highway's effects on the region's landuse, climate and topography is controversial (Uzun 2000). The road is built on the area that was obtained by filling the sea, and it is preventing the rivers flowing vertically to meet the sea. This is causing many problems in the settlements located in the highway route such as severe floods and collapsing and demolishing of the roads. Ordu is the only settlement that the Black Sea Coastal Highway is not passing from the coast. People of Ordu had opposed to the filling of the sea in the construction period of the highway, and as a result the route had been changed and replaced with tunnels passing from the back side of the coast. Even though the highway being on the back side of the settlement had a positive impact on coastal use, it still created an attraction point, and the urban area expanded by sprawling both through the coastline and the highway.

Another subclass of artificial surfaces category that experienced intense transitions especially from forest areas is mineral extraction. With an amendment on the mining law in 2004, obtaining a mining license became easier and it attracted especially foreign investors. The whole Eastern Black Sea Region is rich in mineral deposits but poor in reserves, and while the number of mineral extraction sites were limited before the change in the law because of environmental concerns, the numbers have significantly increased in this process. ${ }^{12}$ Today Ordu has the most mining areas in the Eastern Black Sea Region with 55 mining sites, mostly extracting basalt and bentonite..$^{13}$ In this context, transitions from forest and agricultural areas to mineral extraction sites are posing an important threat for rural and cultural landscapes with the destruction of landcover and consumption of natural resources.

Eastern Black Sea Region is one of the most important regions of Turkey not by the means of the size of agricultural areas but by employment and production stance (Erköse et al. 2020). While Turkey covers for $70 \%$ of worldwide hazelnut demand, Ordu is the agricultural area that has the biggest hazelnut gardens in the country. Eastern Black Sea catchment area that includes Ordu is defined as the first standard region for hazelnut production. It is the first region in the country that produced hazelnut and actually it's the region of older hazelnut trees with low productivity (Eryılmaz \& Kılıç 2019). However, instead of productivity improvement attempts, the inclination is to increase the

12 Dogu Karadeniz Bölgesel Gelişme Planı -Dokap (2000) (Eastern Black Sea Regional Development Plan) Nihai Rapor, Cilt II: Ana Plan, 2000, Türkiye Cumhuriyeti Başbakanlık Devlet Planlama Teşkilatı Müsteşarlığı, Japonya Uluslararası İşbirliği Ajansı-JICA, Ağustos 2000, Nippon Koei Co., Ltd. Recs International Inc.

${ }^{13}$ Doğu Karadeniz Bölge Planı-TR90 (Eastern Black Sea Regional Plan) 20142023, Doğu Karadeniz Kalkınma Ajansı (Eastern Black Sea Development Agency). 
hazelnut gardens in size. This condition is confirmed in the study by detecting the transitions to fruit trees subclass -that includes hazelnut gardens- from other agricultural areas. There are three main reasons causing this situation. First of all, the appeal of the state-sanctioned base price implementation that was executed after 1963 is steering the farmers towards hazelnut production. Secondly, with an implementation that took effect in 2014, hazelnut production areas were restricted, and the new hazelnut planting areas were identified to be in the soil quality class of four or bigger than four. Ordu, where the soil quality is mostly in the seventh class, became appealing. The third reason is perhaps the most remarkable one in terms of the region's cultural structure and life habits; which is the hazelnut's production characteristic that needs handling and attention only one month of the year.

Hazelnut agriculture depends on manual labor production, but for this production that is handled by manual labor, it is sufficient to work intensely for around 30 days a year. During the hazelnut harvest season, there is a significant requirement for seasonal workers in the region. ${ }^{14}$ Eastern Black Sea Region is losing its population considerably since the beginning of the industrialization period both to developed cities inside the country or abroad. However, the migrated population is not cutting their ties to the region and keeping their agricultural land even if it's very small. The fact that hazelnut production only needs 30 days of labor is enabling this situation. This has also become a yearly reoccurring ritual. Locals are always returning to their villages every year in hazelnut harvest season from whichever part of the world they live, whether they own a hazelnut garden or not, and they are contributing to family budget with a lump sum by helping with the hazelnut harvest. As a result, even though the region is losing labor force, agricultural areas (hazelnut gardens) are continuing their presence and so is the agricultural production, and consequently they become the guaranty to return home after retirement. Therefore, the opportunities that Hazelnut product provides are causing the decrease in the productions of other indigenous plants, and the change in landscape characteristics with the rampant expansion of hazelnut plantation areas.

Landscape transitions that are identified in the Eastern Black Sea Region and the city Ordu, which have a unique product pattern, rituals, and a settlement pattern with their cultural structure and landscape shaped by rural production, are signaling the following threats for the future:

\footnotetext{
${ }^{14}$ Kaptan, H. (1978) Doğu Karadeniz Kırsal Alan Yerleşme Düzeni ve Tarımsal Üretim İlişkisi, Eastern (Black Sea Rural Settlement and Agricultural Pro duction Relations) IDMMA-YTÜ, department of Architecture, 1978, Unpublished Research, İstanbul.
}

Urbanized rural landscapes, ambiguous and blurry transition area between rural area and city center or urban area, but most of all urbanized villages (Antrop 2004; Antrop 2014; Zaleskienė \& Vileniškè 2014),

- Operating the mining deposits in an uncontrolled manner with financial concerns, and the destruction it will cause in the nature,

- Contribution to issues like global climate change with productivity loss and product pattern change that is caused by the uncontrolled, unplanned transition from subclasses of agricultural areas to fruit trees class - the subclass of hazelnut agriculture (Agnolettl \& Santoro 2018),

- Destructions in nature caused and will be caused by transportation investments of which the environmental impact assessment studies were not done properly.

With the analyses in this study; landscape transition sizes, ratios, increase periods, and intensities had been identified on the level of landcover main categories and subclasses within the scale of the database used. With the contribution of this study to the next step; estimation studies on these transitions should be made (Agnoletti et al. 2011), and the necessary precautions should be taken. Supporting the analyses made through CORINE data by detailed data collection studies in the region would take the study to more productive levels.

\section{References}

Agnoletti, M. \& Santoro, A. (2018). Rural Landscape Planning and Forest Management in Tuscany (Italy), Forests 2018, 9, 473; doi:10.3390/f9080473.

Agnoletti, M., Cargnello, G., Gardin, L., Santoro, A., Bazzoffi,P., Sansone,L., Pezza, L., Belfiore, N. (2011). Traditional landscape and rural development: comparative study in three terraced areas in northern, central and southern Italy to evaluate the efficacy of GAEC standard 4.4 of cross compliance, Italian Journal of Agronomy 2011; 6(s1): e16, doi:10.4081/ ija.2011.6.s1.e16.

Aldwaik, S.Z., Pontius Jr., R.G. (2012). Intensity Analysis to Unify Measurements of Size and Stationarity of Land Changes by Interval, Category, and Transition, Landscape and Urban Planning, 2012, 106 (2012) 103-114, doi:10.1016/j.landurbplan.2012.02.010.

Antrop, M. (2004). Landscape change and the urbanization process in Europe, Landscape and Urban Planning, 2004, 67 (2004) 9-26, doi:10.1016/S0169-2046(03)00026-4, Elsevier Science.

Antrop, M. (2014). Interpreting diversity in the European landscape. A comment on perspective essays by Agnoletti and Schnitzler, Landscape and Urban Planning 126 (2014) 81-83, http://dx.doi.org/10.1016/j.landurbplan.2014.02.013.

Beilin, R., Lindborg, R., Stenseke, M., Pereira, H.M., Llausàs,A.,Slätmo, E., Cerqueira, Y., Navarro, L., Rodrigues, P., Reichelt, N., Munro, N., Queiroz, C. (2013). Analysing how drivers of ag- 
ricultural land abandonment affect biodiversity and cultural landscapes using case studies from Scandinavia, Iberia and Oceania, Land Use Policy, 36 (2014) 60-72, http://dx.doi. org/10.1016/j.landusepol.2013.07.003 .

Beynon, M.J., Andrew Crawley, A., and Munday, M. (2016). Measuring and understanding the differences between urban and rural areas, Environment and Planning B, Planning and Design, Vol.43(6), 1136-1154, DOI: 10.1177/0265813515605096.

Brown J., Mitchel N., Berford M. (2005). Protected Landscapes: A Conservation Approach that Links Nature, Culture and Community, The Protected Landscape Approach Linking Nature, Culture and Community, (ed.) Brown,Mitchel, Berford, IUCN The World Conservation Union, ISBN 2-8317-0797-8, page: 3-19.

CEMAT (2003). European Rural Heritage Observation Guide, Council Of Europe, 13 CEMAT (2003) 4.

Çopuroğlu, M.A. (2017). Büyükşehir Belediye Sınırları İçinde Yer Alan Kırsal Yerleşmelerin Sorunları Üzerine Bir Değerlendirme (An Evaluation on the Problems of the Rural Settlements in the rural settlement in the metropolitan municipal boundaries) Süleyman Demirel University, Journal of Architecture Science and Applications, JASA (2017) 2(2):18-32, e-ISSN:2548-0170.

Erköse, H.Y., Şahin, O., Yükseker, D., Sert, D.H. (2020). Devlet ve Küresel Piyasa Arasında:karadeniz Blgesinde Küçük Ölçekli Fındık Üretimi, İstanbul Üniversitesi Sosyoloji Dergisi, 40(1):55-77, https://doi.org/1026650/SJ.2020.40.1.0047.

Eryılmaz Aydın, G., Kılıç, O. (2019). Türkiye'nin Organik Fındık Üretimi ve İhracaatındaki Gelişmeler, Fırat Üniversitesi ïBF Uluslararası Iktisadi İdari Bilimler Dergisi, Cilt 3, Sayı 1,2019 41, https://www.researchgate.net/publication/33715197.

Gulinck H., Wagendorp T. (2002). References for Fragmantation Analysis of Rural Matrix in Cultural Landscapes, Landscape and Urban Planning, Vol.58, Issue 2-4, 15 february 2002, pages 137-146, https://doi.org/1016/50169-2046(01)00216-x.

Gürgen, G. (2004). Doğu Karadeniz Blümü’nde Maksimum yağışlar ve Taşkınlar Açısından Önemi (The Maximum rainfalls in Eastern Black Sea Region and their Importance in terms of floods), GÜ Gazi Eğitim Fakültesi Dergisi, Cilt 24, Sayı 2(2004) 79-92, http://www.gefad.gazi.edu.tr/en/download/ article-file/77329.

Kizos, T., Primdahkl, J. (2010). Introduction: Landscape Change and Rural development, Landscape Research, Vol.35,2010, Issue 6, https://doi.org/10.1080/01426397.2010.502749.

Jepsen, M.R. et al. (2015). Transitions in European Land-Management Regimes Between 1800 and 2010, Land Use Policy, 49 (2015) 53-64, http://dx.doi.org/10.1016/j.landusepol.2015.07.003.

Junaid, A.M., Abdulraheem M.O., Adeleye, B.M., (2020). Urban Sprawl and the Challenges of Physical Development Planning in the North-Central Part of Nigeria, The International Journal of the Constructed Environment Volume 11, Issue 1, 2020, https://doi.org/10.18848/2154-8587/CGP/v11i01/1-11.

Li, Z., Li, X., Wang J., Ma, A., Wang, J. (2010). Land-use Change Analysis in Yulin Prefecture Northwestern China Using Re- mote Sensing and GIS, International Journalof Remote Sensing, page5691-5703, https:// doi.org/10.1080/01431160412 331291206.

Rovai, M., Andreoli, M. (2016). A DSS Model for The Governance of Sustainable Rural Landscape: A First Application to the Cultural Landscape of Orcia Valley (Tuscany-Italy), Land Use Policy, Vol.56, November 2016, pages 217-237, https:// doi. org/10.1016/j.lanusepol.2016.04.038.

Rössler, M. (2002). Linking Nature and Culture: World Heritage Cultural Landscapes, Cultural Landscapes: The Challenges of Conservation, World Heritage 2002, Shared Legacy, Common Responsibility, Associated Workshops, 11-12 November 2002-Ferrara-Italy, Publish in 2003 by UNESCO WHC, World Heritage Paper 7, page:10-15.

Rössler, M. (2005). Cultural Landscapes: A Global Perspective, World Heritage The Protected Landscape Approach Linking Nature, Culture and Community, (ed.) Brown,Mitchel, Berford, IUCN The World Conservation Union, ISBN 2-83170797-8, page:37-47.

Salvati, L., Carlucci, M. (2015). Land-use structure, urban growth, and periurban landscape: a multivariate classification of the European cities, Environment and Planning B: Urban Analytics and City Science, September 1, 2015, https://doi. org/10.1068/b120059p.

Stobbelaar, D.J. \& Pedroli, B. (2011). Perspectives on Landscape Identity: A Conceptual Challenge, Landscape Research, Vo.36, No.3, 321-339, June 2011, https://doi.org/10.1080/0 1426397.2011 .564860

Su, S., Jiang Z., Zhang Q., Zhang Y. (2011). Transformation of Agricultural Landscape Under Rapid Urbanization: A Threat to Sustainability in Hang-Jia-Hu Region China, Applied Geography, Volume 31, Issue 2, April 2011, page 439-449, https:// doi.org/10.1016/j.apgeog.2010.10.008

Tieskens, K.F., Schulp, C.J.E., Levers, C., Lieskovsky, J., Kuemmerle, T., Plieninger, T., Verburgg, P.H. (2017). Characterizing European Cultural Landscapes: Accounting for Structure, Management Intensity and Value Of Agricultural and Forest Landscapes, Land Use Policy, 62(2017) 29-39, htts://dx.doi. org/10.1016/j.landusepol.2016.12.001.

Uzun, A. Karadeniz Sahil Yolunun Doğal Kıyılar Üzerindeki Etkileri Ve Ulaşım Sorununa Coğrafi Bir Bakış, 2000, https://www.researchgate.net/publication/324057386.

Wijetunga C.S., Sang Sung J. (2015). Valuating The Cultural Landscapes Past and Present: Tea Plantations in Srilanka, Landscape Research, Vol.40,2015, Issue 6, https://doi.rg/10.1080 /01426397.2015.1057803.

Zaleskienè, E., Gražulevičiūtè-Vileniškè, I. (2014). Guidelines for Landscape Management in the Areas of Rural-Urban Interface : Continuity and Innovation, Architecture and Urban Planning, doi: 10.7250/aup.2014.003.

Zhang, B.; Zhang, O.; Feng, C.; Feng, O.; Zhang, S. (2017). Understanding Land Use and Land Cover Dynamics from 1976 to 2014 in Yellow River Delta, Land, 6, 20. doi:10.3390/ land6010020, www.mdpi.com/journal/land. 